\title{
Identification of Enabling Factor of Early Smoking Behavior towards Students
}

\author{
Rosdiana $^{1}$, Nur Agus Salim ${ }^{2}$ \\ \{anahanur@gmail.com ${ }^{1}$, nuragussalim@uwgm.ac.id $\left.{ }^{2}\right\}$ \\ ${ }^{1,2}$ University of Widya Gama Mahakam, J1. K. H. Wahid Hasyim No. 28 Samarinda, East Borneo
}

\begin{abstract}
This research is aimed investigate perception of EFL students in using Mendeley to help them Early smoking behavior is the beginning of the formation of long-term smoking behavior. Smoking behavior has a detrimental effects in terms of health, economy, social and environment. In terms of health, it is known that a cigarette contains 4000 types of chemicals which is dangerous if it entered human body, whether it swallowed or inhaled, therefore it is necessary to prevent smoking from early age. The aim of the study was to identify Enabling factors of smoking behavior from an early age in students of SMPN 29 Samarinda. The research dimensions were the role of BK teachers, school facilities and infrastructure and students' pocket money. The role of BK teacher is still lacking, because some aspects that need to be considered in students through counseling by BK teachers are not implemented, such as personal, social, learning and career aspects. This is also supported by a lack of facilities and infrastructure, such as no counseling room, application of instrumentation, data collection, data storage devices, technical equipment, and administrative equipment. Pocket money did not affect smoking behavior toward the students. Seeing the function of counseling teacher, the teacher was supposed to be close, familiar and always sought after the students, they should not be avoided or even feared by their students. The adequate infrastructure facilities would support BK service activities to run smoothly as planned. When students did not have pocket money they could get it from their friends, this is initiated by the price of cigarettes which are cheap and easily obtained by students.
\end{abstract}

Keywords: teacher's role, infrastructure, pocket money, smoking behavior

\section{Introduction}

Early smoking behavior is the beginning of forming long-term smoking behavior or smoking addiction. Smoking behavior has a detrimental effects in terms of health, economy, social and environment, Health Ministry of Indonesia [1]. In terms of health, it is known that a cigarette contains 4000 types of chemicals which is dangerous for humman body,[2]. In terms of economic, the cost of cigarette consumption is Rp 338,75 trillion. According to Indonesian Ministry of Health [3], the number of consumption cigarette is six times more than cigarette excise income which is Rp 53,9 trillion.

According to WHO , there are three types of smoker as followed (1) Light smokers, smoke 1 - 10 cigarettes per day, (2) Moderate smokers, smoking 11-20 cigarettes per day, (3) Heavy smokers, smoke more than 20 cigarettes per day. 
On 2015, WHO said that from a survey in Indonesia toward 4.313 students in grade 7-9 on age 13-15 years old (male 2029 students and female 2284 students) in the chosen school, it is found that there were $18.3 \%$ active smoker, with $30,9 \%$ were former smokers (male and female). The result of that study showed that some of young students $<13$ years old had tried to smoke, Indonesian Ministry of Health[4].

The current result of Basic Health Research (Riskedas) 2018 showed that child smoker in Indonesia has significantly increased from 7,2\% in 2013, to 9,1\% in 2018. RPJMN2014-2019 targetted to decrease the prevalence of child smoker become 5,4\% in 2019, (Rikesdas, 2018). Based on that data, Indonesia will face a demographic disaster in 2035 due to the increasing number of smokers in adolescents from year to year.

In line with a survey result from Directorate of Disease Control Ministry of Health and assisted by Samarinda City Health Office it is known that $24 \%$ of junior high school and high school students smoke. This survey was conducted at eight schools in Samarinda towards 320 students of junior and senior high school[3].

The result explained that the reasons of why student smoke is because of the cheap price and the intention of smoke advertisement whether on television or on the billboard[5].

Meanwhile, according to the data from Kaltim Post who have dne a survey toward 90 active smoker respondents in Samarinda, found that $5 \%$ of them began to become smokers at the age of 9-11 years and $42 \%$ of respondents smoke at the age of 15-17 years[6]. The research coordinator team, Erizal Repati mentioned that smokers generally know cigarettes from the surrounding environment, family, and relatives and $37 \%$ respondents said they were willing to endure hunger because of smoking [7].

\section{Method}

This research is Conducted at SMPN 29, South Sempaja, North Samarinda District, Samarinda City, from September 3 to October 6, 2018. The samples taken randomly and selected with consideration 1). The condition of the informants is in accordance with the consideration and the objective of the research and considered to be aware of the situation. 2). Willing to help and be the subject of research and have sufficient time to be asked for information and can cooperate, 3). Teachers and Students of SMPN 29 Samarinda. The number of informants were 5 people consisting of 3 Students, Principals and Counseling Guidance Teachers (BK)[8][9]. Through in-depth interviews, observation and documentation of the informants and school environment,[10]. By using an interactive interaction patterns and takes place continuously until complete, with the result that the data is saturated. The credibility test is done by triangulation method, namely; Source Triangulation is checking data through several sources to fit the research objectives, Triangulation Method is a technique of checking data carried out to the same source with different methods[11].

\section{Findings and Discussion}

\subsection{Findings}

The role of BK teachers in the prevention of smoking from an early age in SMP Negeri 29 is based on the results of interviews with informants, as followed; 
Table. 1 Counseling Aspects of BK Teacher

\begin{tabular}{ll}
\hline Aspects & Counselling Implementation \\
\hline Personal & Never implemented \\
(Self Potential, & \\
Talent, & \\
Interest) & Implemented according to \\
Social & subject matter \\
(Emphaty, & \\
Cooperation, & \\
Overcoming conflicts, & \\
Values \& norms) & \\
Learning & Sometimes \\
(Motivation, & \\
Skilled, & \\
Diligent) & \\
Career & Never implemented \\
(Goal, knowledge) & \\
\hline
\end{tabular}

Based on the data above, the roles and functions of BK teacher do not work as they should. As the following informant revealed:

Excerpt 1

"If there is a friend who is called by BK teacher, it must be a friend who has fighting or there is a problem, because it is usually like that". (W.A.KN.4)

Excerpt 2

"so far ...... I have never found out by the BK teacher if we smoke at school, none of friends have dared to report". (W.B.S.X)

Based on the observations at SMPN 29 Samarinda, the existing facilities and infrastructure are inadequate, where there is no room for guidance and counseling, and no computer set available for BK teachers in carrying out their duties, such as; make program design, data collection, process, analyze and interpret data according to the needs of students, etc. Based on the results of interviews with informants;

Excerpt 3

"We don't have a special room for the BK teacher miss, so if there is a problem with student, we just have a trial here”. (W.A.S.5)

Excerpt 4

"if there is a counseling session, it is usually in the teacher's room so that all the teachers listen miss, especially if it breaks time, sometimes other teachers will blame us, huh ... just ignore it". (W.B.P.A.X)

Besides that facilities and infrastructure to support talent, interests and potential of the students are not sufficient, such as facilities for sports, arts and writing. 


\section{Excerpt 5}

"we don't pay attention to our students that far miss, because there are many tasks in that class that have to be written and reported, so that the remaining time is not enough to explore the talents, interests and potential of our students especially when we want to prepare facilities and infrastructure, we don't have time miss". (W.A.S.5)

Students who smoke at SMPN 29 Samarinda are not affected by their pocket money. This was explained by the informant in the following interview excerpt;

Excerpt 6

"Sometimes I get pocket money, sometimes I don't, if I don't get pocket money, I owe cigarettes to my friends, my firends are often do the same, if they don't get pocket money, I lend them, we take turn, the important thing is we can smoke". (W.A.KN.4)

This is initiated by the price of cigarettes which is very affordable/cheap for students, which is only Rp. 1,500/stick, therefore giving cigarette each other, if their friends do not have pocket money is not burdensome. The following are the results of interviews with the informants;

Excerpt 7

"2 to 4 cigarettes if at school, 2 sticks at break time, 2 more bars if there are empty class hours, I don't count to my fiends if only for 3000 with friends". (W.B.P.A.X)

Excerpt 8

"My pocket money is sometimes 10,000, 15,000, 20,000 sometimes more, it's not certain miss, often 10,000 or 15,000. To buy cigarettes is enough, the proof is that I smoke every day, on average 10 cigarettes per day, whether I get pocket money or not, I smoke every day". (W.B.S.X)

\subsection{Discussion}

According to RI Regulation No. 19 (2017) about teacher, BK teacher is a teacher who who is in charge and responsible in providing services, guidance and counseling, which are educating, guiding and developing the ability of students in solving problems experienced by the stusdents and all potential of the students through guidance and counseling services that are in accordance with the roles and duties of BK teacher.

The assistance provided by BK teachers to students is done in order to make the students to able to develop their existing potential optimally, and students can be useful for themselves, their environment and society in general according to norms in order to achieve the goals and to not be wrong in choosing the solution to the problem.

Smoking behavior in students is a health, economic and social problem (Ministry of Health, 2015). Therefore it needs assistance, and guidance through counseling and approaches by the BK teacher to their students so they can help students stop smoking and develop the talents, interests and potential possessed by students. There are several stages of personal development goals of each student through BK services, including; (a) disclosure, recognition and selfacceptance, (b) introduction to the environment, (c) and decision making, guidance from the BK teacher (2017).

Based on the results of interviews and observations conducted at SMPN 29 Samarinda, for students BK teachers are like a police, who handle students when they have problems, often violate, make noise at school, often late to school and other mischef. Even students like to scare their friends by using their BK teacher's name.

The role of the BK teacher has not run as it should, this is proofen by the behavior of students who even avoid and being afraid to meet with BK teachers. Seeing the function of BK teacher, 
the teacher was supposed to be close, familiar and always sought after the students, they should not be avoided or even feared by their students.

Counseling service activities in schools will run smoothly as planned, if it is supported by adequate infrastructure. According to Minister of Education Regulation No.24 (2007), facilities are the learning equipment that can be moved, while infrastructure is a basic facility for carrying out school functions. It can be concluded, that "the means of guidance and counseling are equipment that is directly used for achieving BK objectives, and infrastructure is the basic equipment for carrying out BK service functions ".

The functions of is as a place for students to get counseling services from counselors related to personal, social, learning and career development, Ministry of Education and Culture (2016). The guidance and counseling process at SMPN 29 Samarinda is quite worrying because the counseling room is narrow and that room also functions as a room for all teachers (teacher's room), so it cannot provide comfortable place and maintain the privacy of students while conducting counseling.

The unavailability of various facilities to support BK activities, such as; (a) instrumentation applications, (b) data sets, (c) data storage devices, (d) technical equipment, (e) administrative equipment, such as; work desks and chairs, computers, filling cabinets, special shelves, bulletin boards, BK schedule boards, document storage cabinets, boxes for storing cards, telephone, guest chairs, if necessary, the placement of CCTV in their own places which is rarely accessed by teacher which is a strategic place for students to smoke.

\section{Conclusion}

Based on above findings and discussion, it can be concluded that smoking behavior in students is not influenced by his pocket money. Sometimes there are smoker students who do not get pocket money from their parents, but still regularly smoke. This is initiated by the price of cigarettes that are cheap / affordable for students and easy to obtain, so it does not become a problem when they hhave to share each other with friends, because sharing cigarettes often occurs between them.

\section{References}

[1] S. W. Sarwono, Psikologi Remaja. Jakarta: PT Raja Grafindo Persada, 2011.

[2] A. L. Kristjansson et al., "Does early exposure to caffeine promote smoking and alcohol use behavior? A prospective analysis of middle school students.," Addiction, Apr. 2018.

[3] S. S. Willis, Remaja \& Masalahnya. Bandung: Alfabeta, 2010.

[4] J. Kim and S. Park, "Adolescent Abuse and Smoking Behavior Among High School Students in the Republic of Korea," J. Child Fam. Stud., 2018.

[5] R. Ghadban, L. Haddad, L. R. 2nd Thacker, K. An, R. L. Balster, and J. Salyer, "Smoking Behaviors in Arab Americans: Acculturation and Health Beliefs.," J. Transcult. Nurs. Off. J. Transcult. Nurs. Soc., vol. 30, no. 2, pp. 115-123, Mar. 2019.

[6] M. A. Han, "The price of tobacco and its e ff ects on smoking behaviors in Korea: The 2015 Korea Community Health Survey,” Prev. Med. (Baltim)., vol. 120, no. January, pp. 71-77, 2019.

[7] P. Morello et al., "Smoking susceptibility as a predictive measure of cigarette and ecigarette use among early adolescents," Salud Publica Mex., vol. 60, no. 4, pp. 423-431, 
2018.

[8] Sugiyono, Metode Penelitian Kuantitatif, Kualitatif, R\&D. Bandung: Alfabeta, 2011

[9] Soekidjo Notoadmodjo, Metode Penelitian Kesehatan. Jakarta: Rineka Cipta, 2010.

[10] L. Fergie, K. A. Campbell, T. Coleman-haynes, M. Ussher, S. Cooper, and T. Coleman, "Addictive Behaviors Reports Stop smoking practitioner consensus on barriers and facilitators to smoking cessation in pregnancy and how to address these: A modified Delphi survey," Addict. Behav. Reports, vol. 9, no. January, p. 100164, 2019.

[11] G. Corey, Teori dan Praktik: Konseling dan Psikoterapi. Bandung: Refika Aditama, 2010. 